\title{
Spatial Distribution of the Natural Radioactivity of the Water and its Association with the Physico- Chemical Parameters: Abu Tig, Assiut, Egypt
}

\author{
Ghada Salaheldin ${ }^{1 *}$, Ahmed Sefelnasr ${ }^{2}$ and Hany El-Gamal ${ }^{1}$ \\ ${ }^{1}$ Department of Physics, Assiut University, Egypt \\ ${ }^{2}$ Department of Geology, Assiut University, Egypt
}

Submission: March 21, 2019; Published: April 18, 2019

*Corresponding author: Ghada Salaheldin, Department of Physics, Faculty of Science, Assiut University, Assiut 71516, Egypt

\begin{abstract}
Activity concentrations of radionuclides $\left({ }^{226} \mathrm{Ra},{ }^{222} \mathrm{Rn},{ }^{232} \mathrm{Th}\right.$ and $\left.{ }^{40} \mathrm{~K}\right)$ and physico-chemical parameters (Temperature, pH-value and total dissolved solids (TDS)) were measured for drinking water samples collected from Abu Tig, Assiut Governorate, Egypt. The samples were measured by gamma-ray spectrometry technique using HPGe detector with specially designed shield. The average activity concentrations were $\left(235.71 \pm 34.04 \mathrm{mBql}^{-1}\right),\left(58.26 \pm 10.29 \mathrm{mBql}^{-1}\right),\left(624.08 \pm 69.29 \mathrm{mBql}^{-1}\right)$ and $\left(0.184 \pm 0.11 \mathrm{Bql}^{-1}\right)$ for ${ }^{226} \mathrm{Ra},{ }^{232} \mathrm{Th}^{40} \mathrm{~K}^{2}$ and ${ }^{222} \mathrm{Rn}$ respectively. The average annual effective doses due to ingestion of these waters were $60.79 \mu \mathrm{Svyr}^{-1}, 74.75 \mu \mathrm{Svyr}^{-1}$, and $41.81 \mu \mathrm{Svyr}^{-1}$ for different age groups adults, children and infants, respectively. There is no correlation between radionuclides and physico-chemical parameters. The obtained results were lower than the reference level of the committed effective dose recommended value $\left(0.1 \mathrm{mSvyr}^{-1}\right)$ as reported by World Health Organization (WHO), indicating to the safe use of the examined water.
\end{abstract}

Keywords: Natural Radioactivity; Annual effective dose; Drinking water; Abu Tig

\section{Introduction}

Most environmental studies provide the best ways to preserve water and improve its quality for the necessity of human life. Water may be a factor for the transport of pollutants by human consumption. The

radionuclides cause health hazard by ingestion and through the human food chain when these radionuclides are taken to the body [1]. So that it is necessary to achieve the minimum radiation exposure to the human body and not skipped the reference dose level (RDL) of the effective annual dose of drinking water consumption of $0.1 \mathrm{mSvyr}^{-1}$ reported by WHO [2].

The main naturally occurring radioactive isotopes in water are uranium isotopes, radium isotopes, and radon isotopes, these radionuclides are mainly soluble in water [3]. The production of these radionuclides in groundwater is mainly from rockwater interactions. The levels of radioactivity in groundwater depends on many factors such as the concentrations of these radionuclides in the aquifer rocks, geomorphology, and lithology other ecological conditions of aquifer [4,5], depending also on chemical reactions and the physical processes of decay along the water-rock interface.
${ }^{226} \mathrm{Ra}$ is an alpha emitter with longest a half-life of $1602 \mathrm{yr}$, it originates from the ${ }^{238} \mathrm{U}$ decay series and its descendant ${ }^{222} \mathrm{Rn}$ has a half-life of $3.8 \mathrm{~d} .{ }^{228} \mathrm{Ra}$ is a beta emitter with a halflife of $5.75 \mathrm{yr}$ and it originates from ${ }^{232} \mathrm{Th}$ series. ${ }^{40} \mathrm{~K}$ is also radioactive and has a half-life of $1.3 x 109 y$. Generally, radium concentrations in surface water range from 0.01 to $0.1 \mathrm{Bql}^{-}$ 1 [6], while its concentration in groundwater can reach values up to $38 \mathrm{Bql}^{-1}$, depending on the factors mentioned previously. ${ }^{222} \mathrm{Rn}$ is produced which is a gaseous radioisotope and diffuses into the pore water of rock formation. The ${ }^{222} \mathrm{Rn}$ concentration in groundwater reaches to $183 \mathrm{Bql}^{-1}$ [7]. The recommended reference level of radon concentration in tap water is $150 \mathrm{Bql}^{-1}$ as considered by [8].

The levels of detection of radon in water research are explained by the sovereignty of granite rocks as well as the rocks of aquifers under investigation. Increased risk of many types of cancer is associated with exposure to radon and its progeny [9]. In addition, the high concentrations of ${ }^{222} \mathrm{Rn}$ in water samples indicate the presence of the radon's parent nuclide ${ }^{226} \mathrm{Ra}$ in the water-rock/soil system, which is known as the health hazard when ingestion during drinking water [10]. 
The present study attempts to report the results of drinking water radium, thorium, potassium and radon survey in Abu Tig, Assiut Governorate, Egypt. The inhabitants of villages and rural areas in the study area are totally dependent on groundwater and on surface water of the Nile River for water supply.

The present work aims to understand the occurrence and classification of natural radionuclides ${ }^{226} \mathrm{Ra},{ }^{232} \mathrm{Th},{ }^{40} \mathrm{~K}$ and ${ }^{222} \mathrm{Rn}$ in drinking water samples from study area and in a first approach to estimate natural radionuclides exposure levels for inhabitants of this region to estimate radiation doses for several ages due to water consumption by people living in this region. The results might provide some helpful information for management of drinking water use.

\section{Materials and Methods}

\section{Description of study areas}

Assiut Governorate is the most populated governorate in Upper Egypt with more than 5 million inhabitants. Abu Tig is a big district within Assiut Governorate that located on the western bank of the river Nile, between Latitudes $26^{\circ} 57^{\prime} 56.8^{\prime \prime}$ and $27^{\circ} 6^{\prime}$ 59.6" $\mathrm{N}$ and Longitudes $31^{\circ} 11^{\prime} 52.9^{\prime \prime}$ and $31^{\circ} 22^{\prime} 10.7^{\prime \prime}$ E. Abu Tig has a surface area of about $129 \mathrm{~km}^{2}$. It has almost 264,087 inhabitants. Physically, it is bounded to the east by the River Nile and bounded on the western side by the Eocene limestone plateau. The drinking water samples were collected from the area under interest in the period of normal water flow rates within the Nile (Figure 1).

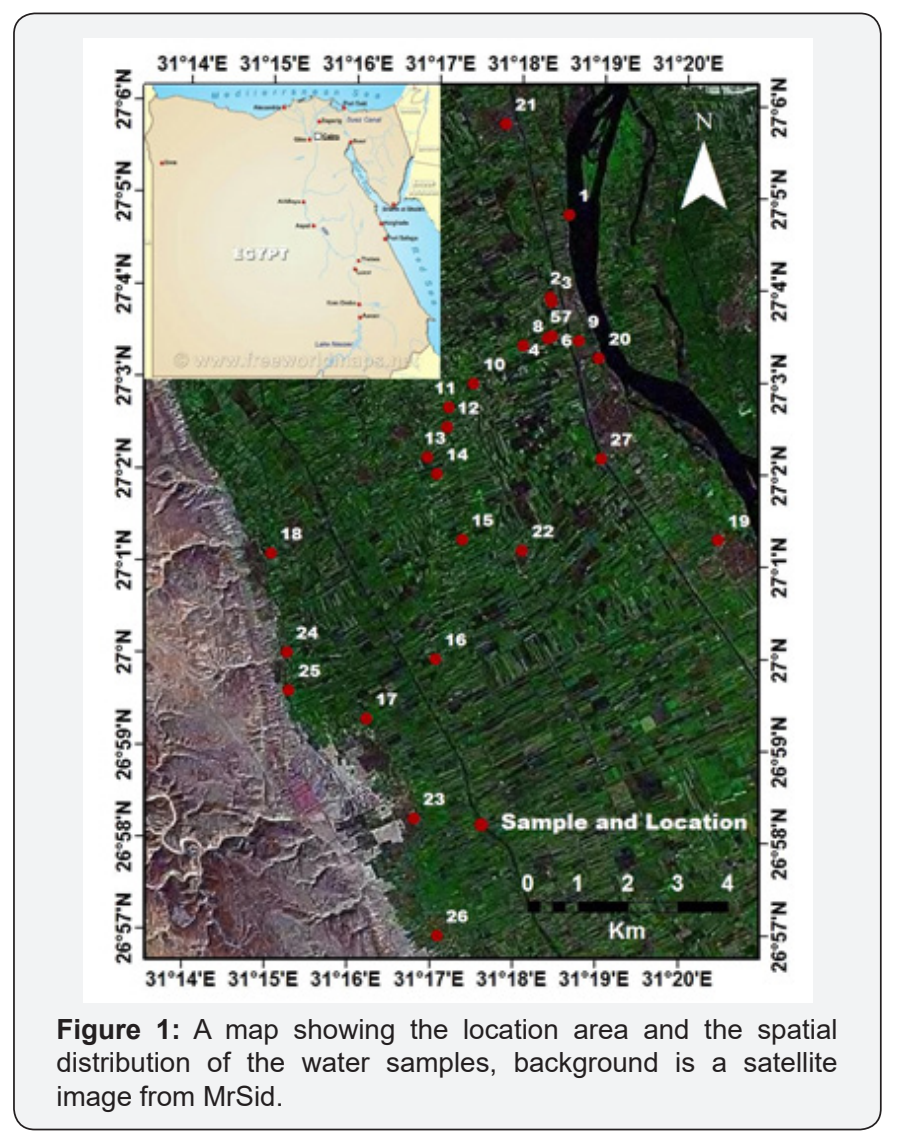

\section{Sampling and sample preparation}

A total of twenty-seven samples were collected from various locations from the study region and classified into three types; surface water, hand-dug wells and deep wells. Standard Polyethylene Marinelli beakers (1 liter) are used as measuring containers. Before utilizing, the containers are washed with $\mathrm{HCl}$ and swilled with distilled water. A tad bit of nitric acid, around $0.5 \mathrm{ml}$ $\mathrm{HNO}_{3}$ per liter, was added to clear solution to forbid any loss of radium isotopes around the container walls, and to avert growth of microorganisms [11]. After filling up the beaker to the brim, a tight cap is pressed on to completely remove the air from it. The samples store for over thirty days to arrive secular equilibrium before a radiometric analysis. Each sample is counted for almost 172800 second relying on the radionuclide's concentrations.

\section{Gamma spectrometry}

Water samples were subjected to a gamma ray spectrometer with a detector had closed-end coaxial Gamma-ray crystal made of high purity germanium in a vertical configuration cooled with liquid nitrogen. The energy resolution of the detector reads approximately $2.000 \mathrm{keV}$ and $\leq 0.925 \mathrm{keV}$ at $1.33 \mathrm{MeV}$ and $122 \mathrm{keV}$, respectively, while the relative efficiency is $40 \mu$. The germanium crystal is existed inside a lead shield to decrease the environmental background. The shield consists of four layers with the following specifications: a low carbon steel of $9.5 \mathrm{~mm}$ thick as an outer jacket, a bulk shield of lead of $10 \mathrm{~cm}$ thickness, and graded linings to absorb low energy X-rays of $1.0 \mathrm{~mm}$ tin and $1.6 \mathrm{~mm}$ copper [12].

The spectrometer was energy-calibrated using radioactive standards of known energies such as ${ }^{137} \mathrm{Cs}(662 \mathrm{keV})$ and ${ }^{60} \mathrm{Co}$ (1172 and $1332 \mathrm{keV}$ ) and it was calibrated for efficiency using Canberra's ISOCS calibration utility instead of standard source [12].

${ }^{226} \mathrm{Ra}$ concentration was determined using gamma-lines of ${ }^{214} \mathrm{Bi}$ and ${ }^{214} \mathrm{~Pb}$ for different energy $(609.31,1120.29$, and $1764.49 \mathrm{KeV})$ and (295.22 and $351.93 \mathrm{KeV}$ ) respectively. The concentration of ${ }^{232} \mathrm{Th}$ was measured using gamma lines of ${ }^{228} \mathrm{Ac},{ }^{212} \mathrm{~Pb}$ and ${ }^{208} \mathrm{Tl}$ for different energy (911.2 and $968.97 \mathrm{KeV}$ ), $(238.63 \mathrm{KeV})$ and (583.19 and $2614 \mathrm{KeV}$ ) respectively. Finally, ${ }^{40} \mathrm{~K}$ concentration was determined one peak at $1460.8 \mathrm{KeV}$.

\section{Dose calculation}

To calculate possibility health hazards, the effective dose radiation, DR ( $\mathrm{mSv} / \mathrm{yr}$ ), doses arising from the ingestion of these waters were assessed using following equation $[8,13]$,

$$
D R=A \times I R \times I D
$$

Where $\mathrm{A}$ is the activity (Bq/L), ID is effective dose equivalent conversion factor $(\mathrm{mSv} / \mathrm{Bq})$, and IR is the ingestion of water for a person in a year (L/yr). The conversion factors for infants $\left(9.6 \times 10^{-4}, 4.5 \times 10^{-4}\right.$ and $\left.4.2 \times 10^{-5} \mathrm{mSv} / \mathrm{Bq}\right)$, for children $\left(8 \times 10^{-4}\right.$, $2.9 \times 10^{-4}$ and $\left.1.3 \times 10^{-5} \mathrm{mSv} / \mathrm{Bq}\right)$ and for adults $\left(2.8 \times 10^{-4}, 2.3 \times 10^{-}\right.$ ${ }^{4}$ and $6.2 \times 10^{-6} \mathrm{mSv} / \mathrm{Bq}$ ), were utilized for ${ }^{226} \mathrm{Ra},{ }^{232} \mathrm{Th}$ and ${ }^{40} \mathrm{~K}$ 
respectively as reported by IAEA, ICRP, and WHO [14-16]. The dose was estimated by knowing consumption rate for adults, children and infants of 730,350 , and $150 \mathrm{~L} / \mathrm{yr}$ respectively.

\section{Results}

Activity concentrations of ${ }^{226} \mathrm{Ra},{ }^{232} \mathrm{Th}$ and ${ }^{40} \mathrm{~K}$ for the drinking water samples collected from various locations in Abu Tig region are listed in Table 1 and shown in Figure 2. The concentrations of ${ }^{226} \mathrm{Ra},{ }^{232} \mathrm{Th}$ and ${ }^{40} \mathrm{~K}$ changed from $59.04 \pm 8.32$ to $421.62 \pm$ $58.11 \mathrm{mBq} / \mathrm{L}$, from $15.58 \pm 2.62$ to $153.07 \pm 33.64 \mathrm{mBq} / \mathrm{L}$ and from $103.27 \pm 11.48$ to $1363.72 \pm 150.98 \mathrm{mBq} / \mathrm{L}$, respectively. The average measurements are $235.71 \pm 34.04 \mathrm{mBq} / \mathrm{L}, 58.26 \pm$ $10.29 \mathrm{mBq} / \mathrm{L}$ and $624.08 \pm 69.29 \mathrm{mBq} / \mathrm{L}$ for ${ }^{226} \mathrm{Ra},{ }^{232} \mathrm{Th}$ and ${ }^{40} \mathrm{~K}$, respectively.

Table 1: Activity concentrations of radionuclides and physico-chemical parameters for water samples in study area.

\begin{tabular}{|c|c|c|c|c|c|c|c|c|c|}
\hline \multirow{2}{*}{$\begin{array}{c}\text { Sample } \\
\text { No. }\end{array}$} & \multicolumn{2}{|c|}{ Coordinates (dms) } & \multicolumn{3}{|c|}{ Physico-Chemical Parameters } & \multicolumn{4}{|c|}{ Activity Concentrations } \\
\hline & $\mathbf{N}$ & $\mathbf{E}$ & pH & TDS (ppt) & $\operatorname{Temp}\left({ }^{\circ} \mathrm{c}\right)$ & ${ }^{226} \mathrm{Ra}\left(\mathrm{mBqL} \mathrm{L}^{-1}\right)$ & ${ }^{232} \mathrm{Th}\left(\mathrm{mBqL}^{-1}\right)$ & ${ }^{40} \mathrm{~K}\left(\mathrm{mBqL}^{-1}\right)$ & ${ }^{222} \mathrm{Rn}\left(\mathrm{BqL}^{-1}\right)$ \\
\hline S1 & $27^{\circ} 4^{\prime} 48.16^{\prime \prime}$ & $31^{\circ} 18^{\prime} 35^{\prime \prime}$ & 8.76 & 0.15 & 26.6 & $257.31 \pm 37.33$ & $65.76 \pm 8.62$ & $419.1 \pm 46.60$ & $0.789 \pm 0.34$ \\
\hline S2 & $27^{\circ} 3^{\prime} 54.18^{\prime \prime}$ & $31^{\circ} 18^{\prime} 21.72^{\prime \prime}$ & 7.85 & 0.43 & 26.6 & $243.47 \pm 35.62$ & $43.22 \pm 5.81$ & $538.84 \pm 59.78$ & $0.470 \pm 0.23$ \\
\hline S3 & $27^{\circ} 3^{\prime} 51.11^{\prime \prime}$ & $31^{\circ} 18^{\prime} 23.21^{\prime \prime}$ & 8.05 & 0.44 & 24 & $165.36 \pm 23.60$ & $153.07 \pm 33.64$ & $984.54 \pm 109.29$ & $0.289 \pm 0.14$ \\
\hline S4 & $27^{\circ} 3^{\prime} 27.6^{\prime \prime}$ & $31^{\circ} 18^{\prime} 20.82^{\prime \prime}$ & 7.82 & 0.37 & 24.9 & $203.54 \pm 28.23$ & $40.53 \pm 6.38$ & $691.84 \pm 76.78$ & $0.208 \pm 0.12$ \\
\hline S5 & $27^{\circ} 3^{\prime} 29.1^{\prime \prime}$ & $31^{\circ} 18^{\prime} 23.64^{\prime \prime}$ & 7.76 & 0.37 & 26.6 & $234.96 \pm 34.93$ & $104.45 \pm 22.70$ & $765.02 \pm 84.94$ & $0.184 \pm 0.11$ \\
\hline S6 & $27^{\circ} 3^{\prime} 29.1^{\prime \prime}$ & $31^{\circ} 18^{\prime} 23.64^{\prime \prime}$ & 7.91 & 0.38 & 25 & $294.52 \pm 41.48$ & $60.99 \pm 8.64$ & $1144.19 \pm 126.65$ & $0.146 \pm 0.10$ \\
\hline S7 & $27^{\circ} 3^{\prime} 29.1^{\prime \prime}$ & $31^{\circ} 18^{\prime} 23.64^{\prime \prime}$ & 7.71 & 0.45 & 24.3 & $177.39 \pm 24.80$ & $40.20 \pm 5.62$ & $571.74 \pm 63.59$ & $0.141 \pm 0.06$ \\
\hline S8 & $27^{\circ} 3^{\prime} 22.8^{\prime \prime}$ & $31^{\circ} 18^{\prime} 2.76^{\prime \prime}$ & 7.78 & 0.45 & 24.9 & $273.93 \pm 39.61$ & $43.38 \pm 5.71$ & $691.84 \pm 76.78$ & $0.109 \pm 0.09$ \\
\hline S9 & $27^{\circ} 3^{\prime} 26.1^{\prime \prime}$ & $31^{\circ} 8^{\prime} 43.38^{\prime \prime}$ & 7.36 & 0.57 & 26 & $78.93 \pm 10.86$ & $55.70 \pm 11.09$ & $178.64 \pm 19.93$ & $0.086 \pm 0.05$ \\
\hline S10 & $27^{\circ} 2^{\prime} 57.36^{\prime \prime}$ & $31^{\circ} 17^{\prime} 27.12^{\prime \prime}$ & 7.49 & 0.95 & 25.5 & $164.44 \pm 24.35$ & $65.01 \pm 10.04$ & $713.51 \pm 79.20$ & $0.165 \pm 0.11$ \\
\hline S11 & $27^{\circ} 2^{\prime} 41.46^{\prime \prime}$ & $31^{\circ} 17^{\prime} 9.12^{\prime \prime}$ & 7.86 & 0.15 & 25.8 & $421.62 \pm 58.11$ & $47.86 \pm 6.37$ & $440.70 \pm 49.02$ & $0.081 \pm 0.05$ \\
\hline S12 & $27^{\circ} 2^{\prime} 28.86^{\prime \prime}$ & $31^{\circ} 17^{\prime} 8.64^{\prime \prime}$ & 7.21 & 0.75 & 24.7 & $275.5 \pm 39.69$ & $71.60 \pm 15.07$ & $738.41 \pm 81.87$ & $0.120 \pm 0.09$ \\
\hline S13 & $27^{\circ} 2^{\prime} 9^{\prime \prime}$ & $31^{\circ} 16^{\prime} 54.54^{\prime \prime}$ & 7.34 & 0.98 & 24.9 & $186.62 \pm 26.70$ & $38.49 \pm 5.34$ & $192.92 \pm 21.50$ & $0.115 \pm 0.08$ \\
\hline S14 & $27^{\circ} 1^{\prime} 58.02^{\prime \prime}$ & $31^{\circ} 17^{\prime} 1.2^{\prime \prime}$ & 7.53 & 0.98 & 24.2 & $214.39 \pm 30.46$ & $25.83 \pm 4.49$ & $412.44 \pm 45.93$ & $0.154 \pm 0.07$ \\
\hline S15 & $27^{\circ} 1^{\prime} 15.42^{\prime \prime}$ & $31^{\circ} 17^{\prime} 20.46^{\prime \prime}$ & 7.78 & 0.67 & 26.5 & $59.04 \pm 8.32$ & $19.88 \pm 3.08$ & $103.27 \pm 11.48$ & $0.146 \pm 0.10$ \\
\hline S16 & $26^{\circ} 59^{\prime} 57.72^{\prime \prime}$ & $31^{\circ} 17^{\prime} 1.98^{\prime \prime}$ & 7.61 & 0.71 & 25.5 & $134.11 \pm 18.1$ & $15.58 \pm 2.62$ & $327.47 \pm 36.31$ & $0.120 \pm 0.10$ \\
\hline S17 & $26^{\circ} 59^{\prime} 18.18^{\prime \prime}$ & $31^{\circ} 16^{\prime} 12.36^{\prime \prime}$ & 7.3 & 0.38 & 25.1 & $121.61 \pm 17.64$ & $28.40 \pm 6.05$ & $518.33 \pm 57.33$ & $0.187 \pm 0.12$ \\
\hline S18 & $27^{\circ} 1^{\prime} 5.3^{\prime \prime}$ & $31^{\circ} 15^{\prime} 1.6^{\prime \prime}$ & 7.72 & 0.63 & 23.7 & $298.82 \pm 43.06$ & $50.60 \pm 10.38$ & $172.96 \pm 19.30$ & $0.159 \pm 0.11$ \\
\hline S19 & $27^{\circ} 1^{\prime} 17.1^{\prime \prime}$ & $31^{\circ} 20^{\prime} 26^{\prime \prime}$ & 7.98 & 0.32 & 25.6 & $213.29 \pm 30.02$ & $77.04 \pm 10.84$ & $126.39 \pm 14.08$ & $0.130 \pm 0.10$ \\
\hline S20 & $27^{\circ} 3^{\prime} 14.9^{\prime \prime}$ & $31^{\circ} 18^{\prime} 57.9^{\prime \prime}$ & 8.13 & 0.22 & 24.6 & $237.43 \pm 34.47$ & $52.36 \pm 6.81$ & $798.28 \pm 88.55$ & $0.116 \pm 0.10$ \\
\hline S21 & $27^{\circ} 5^{\prime} 47.1^{\prime \prime}$ & $31^{\circ} 17^{\prime} 47.9^{\prime \prime}$ & 7.89 & 0.28 & 25.9 & $273.16 \pm 39.23$ & $39.42 \pm 4.09$ & $312.66 \pm 34.84$ & $0.180 \pm 0.08$ \\
\hline S22 & $27^{\circ} 1^{\prime} 8.8^{\prime \prime}$ & $31^{\circ} 18^{\prime} 4^{\prime \prime}$ & 7.95 & 0.28 & 22.9 & $145.92 \pm 22.27$ & $42.73 \pm 7.06$ & $878.1 \pm 98.37$ & $0.204 \pm 0.12$ \\
\hline S23 & $26^{\circ} 58^{\prime} 13.8^{\prime \prime}$ & $31^{\circ} 16^{\prime} 48.2^{\prime \prime}$ & 7.89 & 0.38 & 23.1 & $287.57 \pm 42.52$ & $71.35 \pm 13.89$ & $1363.72 \pm 150.98$ & $0.135 \pm 0.06$ \\
\hline S24 & $27^{\circ} 0^{\prime} 0.9^{\prime \prime}$ & $31^{\circ} 15^{\prime} 14.2^{\prime \prime}$ & 8.46 & 0.16 & 18.2 & $319.86 \pm 49.73$ & $63.99 \pm 13.36$ & $665.23 \pm 73.99$ & $0.146 \pm 0.10$ \\
\hline S25 & $26^{\circ} 59^{\prime} 36.2^{\prime \prime}$ & $31^{\circ} 15^{\prime} 16^{\prime \prime}$ & 8.05 & 0.22 & 25.5 & $369.09 \pm 51.92$ & $69.23 \pm 12.63$ & $798.28 \pm 88.63$ & $0.122 \pm 0.10$ \\
\hline S26 & $26^{\circ} 56^{\prime} 57.7^{\prime \prime}$ & $31^{\circ} 17^{\prime} 5.8^{\prime \prime}$ & 7.91 & 0.25 & 26.2 & $298.33 \pm 44.46$ & $36.07 \pm 4.8$ & $1270 \pm 140.80$ & $0.104 \pm 0.06$ \\
\hline S27 & $27^{\circ} 2^{\prime} 9.4^{\prime \prime}$ & $31^{\circ} 19^{\prime} 0.3^{\prime \prime}$ & 8.39 & 0.09 & 19.9 & $413.98 \pm 61.69$ & $150.18 \pm 32.63$ & $1031.11 \pm 114.29$ & $0.156 \pm 0.11$ \\
\hline Min & & & & & & $59.04 \pm 8.32$ & $15.58 \pm 2.62$ & $103.27 \pm 11.48$ & $0.081 \pm 0.05$ \\
\hline Max & & & & & & $421.62 \pm 58.11$ & $153.07 \pm 33.64$ & $1363.72 \pm 150.98$ & $0.789 \pm 0.34$ \\
\hline $\begin{array}{l}\text { Average } \\
\text { value }\end{array}$ & & & & & & $235.71 \pm 34.04$ & $58.26 \pm 10.29$ & $624.08 \pm 69.29$ & $0.184 \pm 0.11$ \\
\hline
\end{tabular}




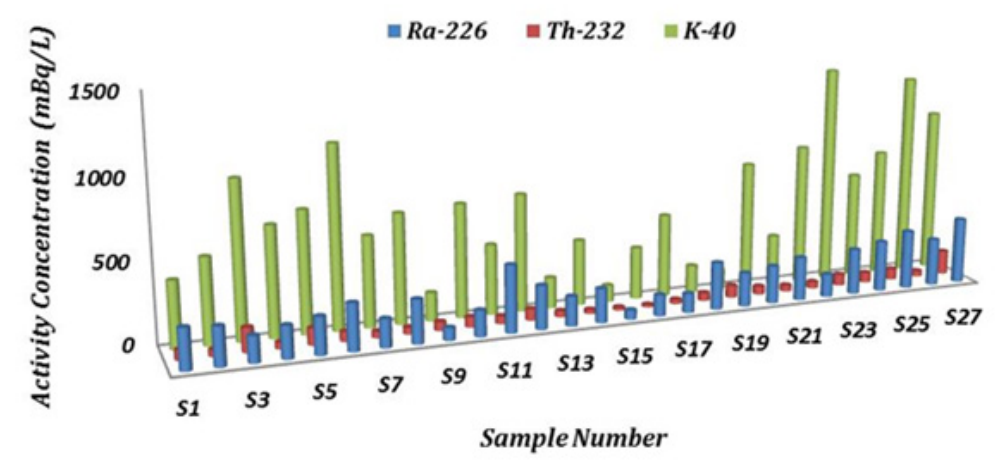

Figure 2: Activity concentrations of ${ }^{226} \mathrm{Ra},{ }^{232} \mathrm{Th}$ and ${ }^{40} \mathrm{~K}$ of water samples in Abu Tig region.

According to the data, ${ }^{226} \mathrm{Ra}$ concentration in most drinking water samples is very higher than the maximum contaminant levels (MCL) of $0.185 \mathrm{~Bq} / \mathrm{L}$ proposed in the USA [9] for drinking water. In addition, the current work is compared to a number of researches in different regions of the world which have lower values, such as reported in Egypt [17], Sudan [18], Malaysia [19], Jordan [20] and Ghana [21], as well as those with higher values as reported in Yemen [22] and Nigeria [23]. Table 2 includes a comparison of ${ }^{232} \mathrm{Th}$ and ${ }^{40} \mathrm{~K}$ concentrations with Different values around the world.

Table 2: The activity concentration $(\mathrm{Bq} / \mathrm{L})$ of drinking water samples in the present investigation compared to other regions in the world.

\begin{tabular}{|c|c|c|c|c|c|c|}
\hline \multirow{2}{*}{ Country } & \multirow{2}{*}{ Type Water } & \multicolumn{4}{|c|}{ Activity Concentration in $\mathrm{Bq} / \mathrm{L}$} & \multirow{2}{*}{ Reference } \\
\hline & & ${ }^{226} \mathbf{R a}$ & ${ }^{232} \mathrm{Th}$ & ${ }^{40} \mathbf{K}$ & ${ }^{222} \mathbf{R n}$ & \\
\hline \multirow{2}{*}{ Egypt (Abu Tig) } & Drinking water & $0.059-0.422$ & $0.0156-0.1531$ & $0.103-1.363$ & $0.081-0.789$ & Present work \\
\hline & & Mean 0.236 & Mean 0.058 & Mean 0.624 & Mean 0.184 & \\
\hline Egypt (Qena) & Groundwater & Mean 0.08 & Mean 0.04 & - & - & (Ahmed, 2004) \\
\hline \multirow{2}{*}{ Egypt (Qena) } & Tap water & - & -_- & - & $0.0061-0.118$ & (Abbady, et al. 1995) \\
\hline & & & & & Mean 0.077 & \\
\hline Yemen (Juban) & Groundwater & $2.25-3.45$ & $0.3-1.43$ & $26.73-43.7$ & - & (El-Mageed,et al. 2013) \\
\hline Sudan & Groundwater & $0.007-0.014$ & 0.001-0.039 & - & - & (osman, et al.2008) \\
\hline $\begin{array}{l}\text { Santos region, } \\
\text { Brazil }\end{array}$ & Surface water & - & - & - & $0.4-2.4$ & (Marques, et al.2004) \\
\hline China & Groundwater & Max 0.93 & $\ldots$ & - & - & (Zhuo,et al. 2001) \\
\hline Sweden & Groundwater & $0.016-4.9$ & & & & (Saleh,et al. 2002) \\
\hline Malaysia & Drinking water & 0.0182 & 0.0389 & 1.22 & - & (Yussuf et al. 2012) \\
\hline Ghana & Surface water & Mean 0.0137 & Mean 0.0012 & & & (Kpeglo et al.2014) \\
\hline Nigeria (Lakes) & Surface water & Mean 12 & Mean 12 & Mean 97 & & (Agbalagba \& onoja, 2011) \\
\hline Malaysia (Panang) & & - & - & - & $0.580-2.540$ & (Muhammed, et al. 2012) \\
\hline Jordan (Irbid) & Tap water & $0.019-0.302$ & 0.024-0.119 & $0.101-0.342$ & - & (Al-Shboul et al.2017) \\
\hline \multirow{2}{*}{ Ghana (Adentan) } & Groundwater & - & $\ldots$ & - & 0.037-0.673 & ( Nguelem, et al.2013) \\
\hline & & & & & Mean 0.392 & \\
\hline
\end{tabular}

There is no clear correlation between ${ }^{226} \mathrm{Ra},{ }^{232} \mathrm{Th}$ and ${ }^{40} \mathrm{~K}$ in this study region, where a weak correlation can be found between $\left({ }^{226} \mathrm{Ra}\right.$ and $\left.{ }^{232} \mathrm{Th}\right),\left({ }^{226} \mathrm{Ra}\right.$ and $\left.{ }^{40} \mathrm{~K}\right)$ and $\left({ }^{232} \mathrm{Th}\right.$ and $\left.{ }^{40} \mathrm{~K}\right)$ with a correlation coefficient of $\mathrm{R}^{2}=0.1156,0.1551$ and 0.1794 , respectively.

${ }^{222} \mathrm{Rn}$ activity concentration in drinking water samples fluctuated between $0.081 \pm 0.05$ to $0.789 \pm 0.34 \mathrm{~Bq} / \mathrm{L}$ with an average value of $0.184 \pm 0.11$, All the samples are below the maximum contaminant level (MCL) of $11.1 \mathrm{BqL}^{-1}[24]$ and $11 \mathrm{BqL}^{-1}$ as proposed by the US Environmental Protection Agency [25] the concentration of radon changes depending on the zone resulting from its geological structure. as well as, the depth of the source of water, do not rule out climate change and geo-hydrological processes occurring in the region [26]. ${ }^{222} \mathrm{Rn}$ concentration in present work is greater than that reported in Egypt [27] and less than that reported from other countries, as Table 2. 


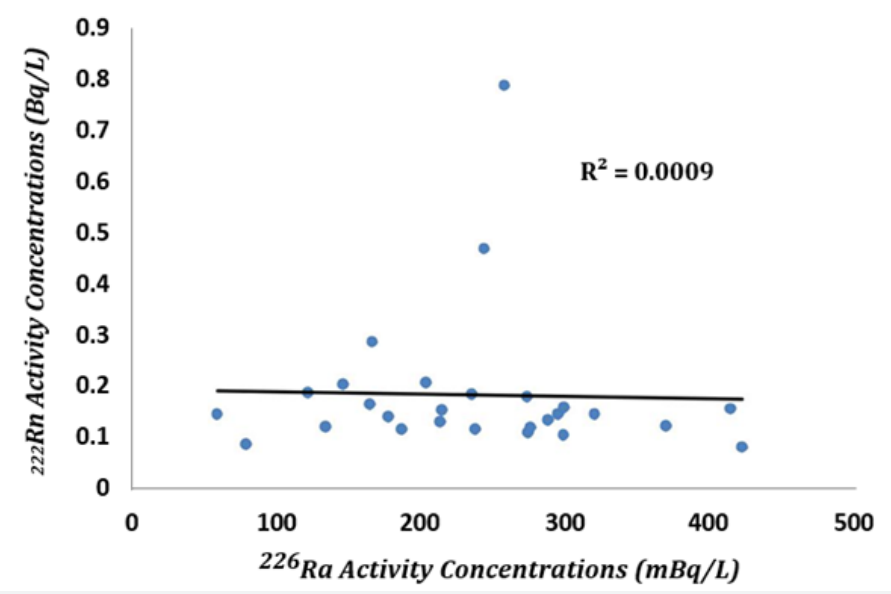

Figure 3: Correlation between the ${ }^{222} \mathrm{Rn}$ and ${ }^{226} \mathrm{Ra}$ concentrations for drinking water samples in study region.

${ }^{222} \mathrm{Rn}$ and ${ }^{226} \mathrm{Ra}$ activity concentrations are listed in Table 1. There is no correlation between them where the correlation coefficients $\mathrm{R}^{2}=0.0009$ as shown in Figure 3 .

Physico-chemical properties of drinking water samples in study region are listed in Table 1. TDS, pH-value and water temperature ranged from 0.09 to $0.98 \mathrm{ppt}$, from 7.21 to 8.76 and from 18.2 to $26.6^{\circ} \mathrm{C}$, respectively. There is no correlation between physico-chemical parameters and radionuclides ${ }^{226} \mathrm{Ra},{ }^{232} \mathrm{Th},{ }^{40} \mathrm{~K}$ and ${ }^{222} \mathrm{Rn}$ where the correlation coefficients $\mathrm{R}^{2}$ in all cases are less than 0.2 as shown in Figure 4, except a moderate correlation was observed between ${ }^{226} \mathrm{Ra}$ activity concentration and $\mathrm{pH}$-value and TDS with correlation coefficient $\mathrm{R}^{2}=0.2159$ and 0.2667 respectively. Also, between ${ }^{222} \mathrm{Rn}$ activity concentration and $\mathrm{pH}$ value with correlation coefficient $\mathrm{R}^{2}=0.2527$.
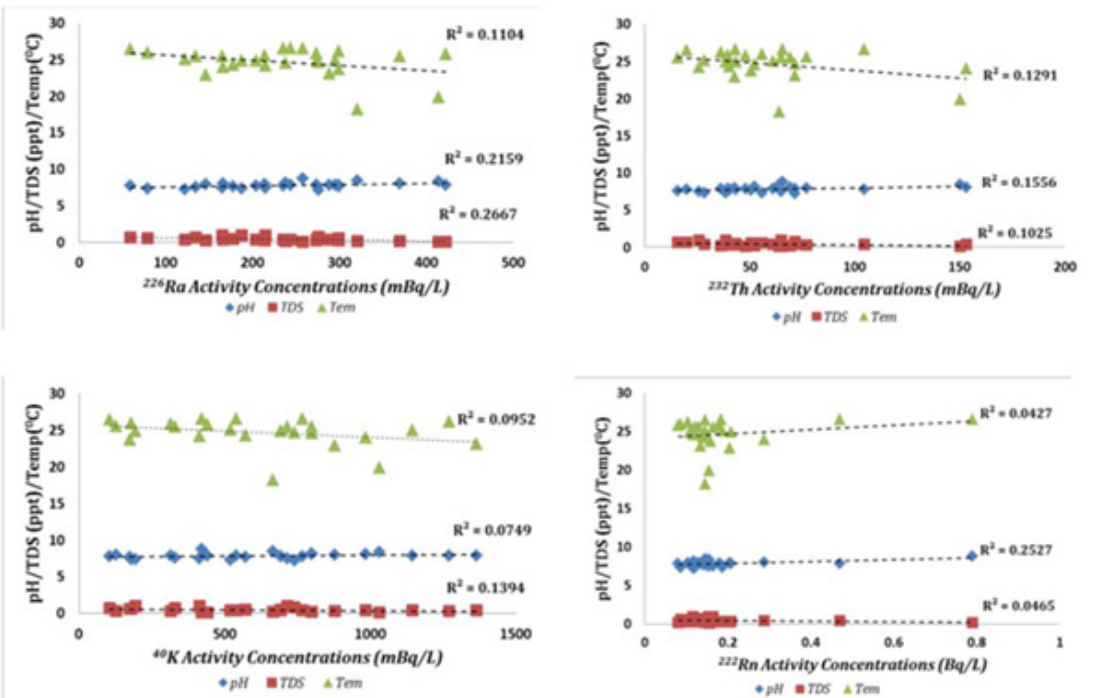

Figure 4: Correlation between ${ }^{226} \mathrm{Ra},{ }^{232} \mathrm{Th},{ }^{40} \mathrm{~K}$ and ${ }^{222} \mathrm{Rn}$ Activity concentrations and the physio-chemical properties for drinking water in study region.

\section{The Annual Effective Dose}

The annual effective doses are given in Table 3 for various ages: adults, children and infants due to ingestion of ${ }^{226} \mathrm{Ra},{ }^{232} \mathrm{Th}$ and ${ }^{40} \mathrm{~K}$ through drinking water from different areas in study region. The annual effective dose fluctuated between 10.49 to $76.25 \mu \mathrm{Svyr}^{-1}$ with an average value of $41.81 \mu \mathrm{Svyr}^{-1}$, between 19.02 to $135.85 \mu \mathrm{Svyr}^{-1}$ with an average value of $74.75 \mu \mathrm{Svyr}^{-1}$ and between 15.87 to $114.50 \mu \mathrm{Svyr}^{-1}$ with an average value of
$60.79 \mu \mathrm{Svyr}^{-1}$ for infants, children and adults respectively. Figure 5 shows that doses received by children were higher than that received by infants and adults; this is because children have small bodies. They are in the developmental stage, because their organs and bones are not yet complete. Therefore, the dose which they are exposed to is large compared to adults. In addition to being shorter than adults, they may get a higher dose of radioactive distributed in and deposited on the ground [28]. 


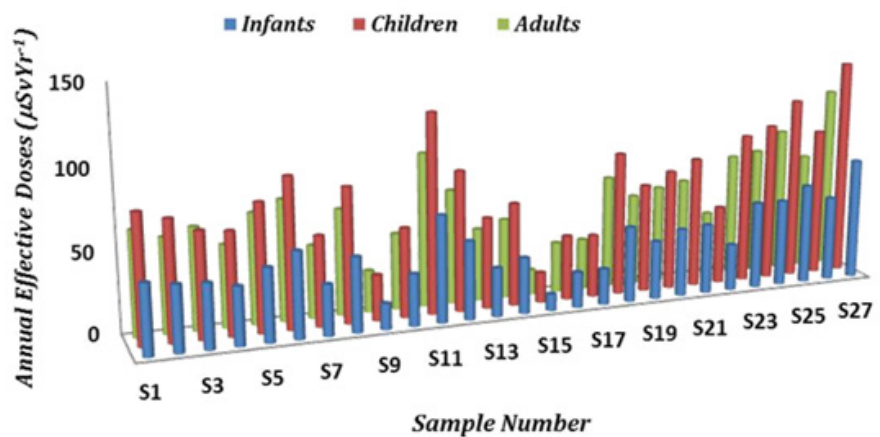

Figure 5: The annual effective doses $\left(\mu S_{v y r}{ }^{-1}\right)$ for infants, children and adults due to intake for drinking water in study region.

Table 3: The annual effective doses ( $\mu \mathrm{Sv} / \mathrm{yr}$ ) due to ingestion of ${ }^{226} \mathrm{Ra},{ }^{232} \mathrm{Th}$ and ${ }^{40} \mathrm{~K}$ for various age groups in Abu Tig region.

\begin{tabular}{|c|c|c|c|c|c|c|c|c|c|c|c|c|}
\hline \multicolumn{13}{|c|}{ Annual Effective Dose $(\mu \mathrm{Sv} / \mathrm{yr})$} \\
\hline \multirow{2}{*}{$\begin{array}{c}\text { Sample } \\
\text { No. }\end{array}$} & \multicolumn{2}{|c|}{ 226Ra } & \multicolumn{3}{|c|}{$232 \mathrm{Th}$} & \multicolumn{3}{|c|}{$40 \mathrm{~K}$} & \multicolumn{4}{|c|}{ Total Dose $(\mu \mathrm{Sv} / \mathrm{yr})$} \\
\hline & Infants & Children & Adults & Infants & Children & Adults & Infants & Children & Adults & Infants & Children & Adults \\
\hline S1 & 37.053 & 72.047 & 52.594 & 4.439 & 6.6751 & 11.042 & 2.64 & 1.907 & 1.897 & 44.132 & 80.629 & 65.533 \\
\hline S2 & 35.06 & 68.173 & 49.766 & 2.918 & 4.3871 & 7.257 & 3.395 & 2.452 & 2.439 & 41.372 & 75.011 & 59.462 \\
\hline S3 & 23.812 & 46.3 & 33.799 & 10.332 & 15.537 & 25.7 & 6.203 & 4.48 & 4.456 & 40.346 & 66.317 & 63.956 \\
\hline S4 & 29.31 & 56.992 & 41.604 & 2.736 & 4.114 & 6.805 & 4.359 & 3.148 & 3.131 & 36.404 & 64.254 & 51.54 \\
\hline S5 & 33.834 & 65.789 & 48.026 & 7.051 & 10.602 & 17.537 & 4.82 & 3.481 & 3.462 & 45.704 & 79.872 & 69.026 \\
\hline S6 & 42.411 & 82.466 & 60.2 & 4.117 & 6.191 & 10.24 & 7.208 & 5.206 & 5.179 & 53.736 & 93.863 & 75.619 \\
\hline S7 & 25.544 & 49.67 & 36.259 & 2.713 & 4.08 & 6.749 & 3.602 & 2.601 & 2.588 & 31.86 & 56.351 & 45.596 \\
\hline S8 & 39.446 & 76.701 & 55.992 & 2.928 & 4.403 & 7.284 & 4.359 & 3.148 & 3.131 & 46.733 & 84.252 & 66.407 \\
\hline S9 & 11.365 & 22.1 & 16.133 & 3.76 & 5.653 & 9.351 & 1.125 & 0.813 & 0.809 & 16.25 & 28.565 & 26.292 \\
\hline S10 & 23.68 & 46.044 & 33.612 & 4.388 & 6.599 & 10.916 & 4.495 & 3.246 & 3.229 & 32.563 & 55.889 & 47.757 \\
\hline S11 & 60.713 & 118.05 & 86.178 & 3.23 & 4.857 & 8.035 & 2.776 & 2.005 & 1.995 & 66.719 & 124.92 & 96.208 \\
\hline S12 & 39.672 & 77.141 & 56.313 & 4.833 & 7.267 & 12.021 & 4.652 & 3.36 & 3.342 & 49.16 & 87.77 & 71.68 \\
\hline S13 & 26.873 & 52.254 & 38.145 & 2.598 & 3.906 & 6.462 & 1.215 & 0.878 & 0.873 & 30.69 & 57.04 & 45.48 \\
\hline S14 & 30.872 & 60.029 & 43.821 & 1.744 & 2.622 & 4.338 & 2.598 & 1.877 & 1.867 & 35.21 & 64.53 & 50.03 \\
\hline S15 & 8.5012 & 16.53 & 12.067 & 1.342 & 2.018 & 3.338 & 0.651 & 0.47 & 0.467 & 10.49 & 19.02 & 15.87 \\
\hline S16 & 19.313 & 37.553 & 27.414 & 1.051 & 1.581 & 2.615 & 2.063 & 1.489 & 1.482 & 22.43 & 40.62 & 31.51 \\
\hline S17 & 17.511 & 34.05 & 24.857 & 1.917 & 2.883 & 4.768 & 3.266 & 2.358 & 2.346 & 22.69 & 39.29 & 31.97 \\
\hline
\end{tabular}

The estimated average values for the annual effective dose for adults, children, and infants approximately $\% 60.79, \% 37.38$ and $\% 16$ of the recommended reference values of 100, 200 and $260 \mu \mathrm{Svy}^{-1}$ respectively [14,16,29-34].

\section{Conclusion}

The present study is a contribution to study behavior and distribution of radioactivity levels of ${ }^{226} \mathrm{Ra},{ }^{222} \mathrm{Rn},{ }^{232} \mathrm{Th}$ and ${ }^{40} \mathrm{~K}$ which measured in drinking water from densely populated area, which is Abu Tig city, Assiut Governorate, Egypt, using gamma-ray spectrometry technique using HPGe detector. The results clearly showed low concentrations of activity in the studied area. The presence of ${ }^{40} \mathrm{~K}$ in groundwater is attributed to the anthropogenic activities represented by the application of the agricultural fertilizers. The results of this study include the assessment of annual effective dose for adults, children and infants. The results of doses which received by children are the highest. The average annual effective doses for all radionuclides of drinking water consumption per year is much less than the recommended reference level and consequentially, therefore recommend that, the water that has been investigated be acceptable for human consumption for life. There is no clear correlation between ${ }^{226} \mathrm{Ra}$ and ${ }^{222} \mathrm{Rn}$, as well as, no correlation between physico-chemical parameters and radionuclides. 


\section{References}

1. Malanca A, Repetti M, de Macêdo HR (1998) Gross alpha-and betaactivities in surface and ground water of Rio Grande do Norte, Brazil. Appl Radiat Isot 49(7): 893-898.

2. WHO, World Health Organization (1998) Guidelines for drinkingwater quality: recommendations (Vol 1): World Health Organization.

3. Abdurabu WA, Ramli AT, Saleh MA, Heryansyah A (2016) The activity concentrations of ${ }^{222} \mathrm{Rn}$ and corresponding health risk in groundwater samples from basement and sandstone aquifer; the correlation to physicochemical parameters. Radiation Physics and Chemistry 127 34-41.

4. Kraemer TF, Genereux DP (1998) Isotope tracers in catchment hydrology. In: McDonnell JJ, Kendall C (Eds.), Applications of Uraniumand Thorium-Series Radionuclides in Catchment Hydrology Studies. Amsterdam, Netherlands, pp. 679-722.

5. Porcelli D (2008) Investigating ground water processes using $U$ and $T h$ series nuclides. In: Krishnaswami S, Cochran JK (Eds.), Radioactivity in the Environment 13: 105-152.

6. Iyengar MAR (1990) The natural distribution of radium. The environmental behavior of radium, Technical Reports Series No. 310, International Atomic Energy Agency, Vienna, pp. 59-128.

7. NCRP (National Council on Radiation Protection and Measurements) (1984) Exposures from the Uranium Series with Emphasis on Radon and its Daughters. NCRP Report No. 77, Bethesda, MD.

8. EPA (Environmental Protection Agency) (1999) Final draft for the drinking water criteria document on radium, US Environmental Protection Agency, Washington, DC, Tr-1241-85.

9. USEPA (U.S Environmental Protection Agency) (1999) National primary drinking water regulation; radon-222, Proposed Rule.

10. Pohl-Rüling J, Hofmann W (2002) Investigation of cancer mortality in the Gastein Valley, an area of high-level natural radiation. International Congress Series 1236: 27-29.

11. Navratil JD, Greenwell RD, Macasek F (1997) Radioactive waste management and environment restoration. Paper presented at the Proc Int Conf Singapore.

12. Canberra (2013) Germanium Detectors User's Manual. Canberra Industries, Inc, all rights reserved.

13. Degerlier M, Karahan G (2010) Natural radioactivity in various surface waters in Adana, Turkey. Desalination 261(1-2): 126-130.

14. IAEA (International Atomic Energy Agency) (1996) International Basic Safety Standards for Protection against Ionizing Radiation and for the Safety of Radiation Sources. Safety Series 15, Vienna.

15. ICRP (International Commission on Radiological Protection) (1996) Age-dependent Doses to Members of the Public from intake of Radionuclides: Part 5 Compilation of Ingestion and Inhalation Dose Coefficients (ICRP Publication 72): IOP Publishing, UK.

16. WHO (World Health Organization) (2003) Guidelines for Drinking Water Quality? World Nuclear Vol. 3-Chapter 9 Drafts, Geneva, Switzerland.

17. Ahmed NK (2004) Natural Radioactivity of Ground and Drinking Water in Some Areas of Upper Egypt. Turkish J Eng Env Sci 28: 345-354.

18. Osman AAA, Salih I, Shaddad IA, El Din S, Siddeeg MB, et al. (2008) Investigation of natural radioactivity levels in water around Kadugli, Sudan. Applied Radiation and Isotopes 66(11): 1650-1653.
19. Yussuf NM, Hossain I, Wagiran H (2012) Natural radioactivity in drinking and mineral water in Johor Bahru (Malaysia). Scientific Research and Essays 7(9): 1070-1075.

20. Al-Shboul KF, Alali AE, Batayneh IM, Al-Khodire HY (2017) Radiation hazards and lifetime risk assessment of tap water using liquid scintillation counting and high-resolution gamma spectrometry. J Environ Radioact 178-179: 245-252.

21. Kpeglo DO, Mantero J, Darko EO, Emi-Reynolds G, Akaho EH, et al. (2014) Radiological exposure assessment from soil, underground and surface water in communities along the coast of a shallow water off shore oilfield in ghana. Radiat Prot Dosimetry 163(3): 341-352.

22. El-Mageed AIA, El-Kamel AH, Abbady AB, Harb S, Saleh II (2013) Natural radioactivity of ground and hot spring water in some areas in Yemen. Desalination 321: 28-31.

23. Agbalagba EO, Onoja RA (2011) Evaluation of natural radioactivity in soil, sediment and water samples of Niger Delta (Biseni) flood plain lakes, Nigeria. J Environ Radioact 102(7): 667-671.

24. WHO (World Health Organization) (2008) Guidelines for Drinkingwater Quality [electronic resource]: incorporating $1^{\text {st }}$ and $2^{\text {nd }}$ addenda, Vol 1, Recommendations.

25. EPA (Environmental Protection Agency) (1991) Final draft for the Drinking Water Criteria Document on Radium. U.S. Washington, DC, TR-1241-85.

26. Althoyaib SS, El-Taher A (2015) Natural radioactivity measurements in groundwater from Al-Jawa, Saudi Arabia. Journal of Radioanalytical and Nuclear Chemistry 304(2): 547-552.

27. Abbady A, Ahmed NK, Saied MH, El-Kamel AH, Ramadan S (1995) Variation of ${ }^{222} \mathrm{Rn}$ concentration in drinking water in Qena Bull Fac Sci 24: 101-106.

28. UNSCEAR (United Nations Scientific Committee on the Effects of Atomic Radiation) (2013) Sources, effects and risks of ionizing radiation, Report to the General Assembly with Scientific Annexe B. New York: United Nations, USA.

29. UNSCEAR (United Nations Scientific Committee on the Effects of Atomic Radiation) (2000) Report to the General Assembly. Annex B: Exposure from Natural Radiation Sources. United National, New York, USA.

30. Marques AL, Dos Santos W, Geraldo LP (2004) Direct measurements of radon activity in water from various natural sources using nuclear track detectors. Appl Radiat Isot 60(6): 801-804.

31. Muhammad BG, Jaafar MS, Azhar AR, Akpa TC (2012) Measurements of Rn-222 activity concentration in domestic water sources in Penang, Northern Peninsular Malaysia. Radiat Prot Dosimetry 149(3): 340346 .

32. Nguelem EJM, Darko EO, Ndontchueng MM, Schandorf C, Akiti TT, et al. (2013) Assessment of Natural Radioactivity Level in Groundwater from Selected Areas in Accra Metropolis. Research Journal of Environmental and Earth Sciences 5(2): 85-93.

33. Isam Salih MM, Pettersson HB, Lund E (2002) Uranium and thorium series radionuclides in drinking water from drilled bedrock wells: Correlation to geology and bedrock radioactivity and dose estimation. Radiat Prot Dosimetry 102(3): 249-285.

34. Zhuo W, Iida T, Yang X (2001) Occurrence of ${ }^{222} \mathrm{Rn},{ }^{226} \mathrm{Ra},{ }^{228} \mathrm{Ra}$ and $\mathrm{U}$ in groundwater in Fujian Province, China. J Environ Radioact 53(1): 111-120. 
CC (P) This work is licensed under Creative
Your next submission with Juniper Publishers will reach you the below assets

- Quality Editorial service

- Swift Peer Review

- Reprints availability

- E-prints Service

- Manuscript Podcast for convenient understanding

- Global attainment for your research

- Manuscript accessibility in different formats ( Pdf, E-pub, Full Text, Audio)

- Unceasing customer service

Track the below URL for one-step submission https://juniperpublishers.com/online-submission.php 